Journal of Engineering Sciences, Assiut University, Vol. 37, No. 1, pp.193 -215, January 2009.

\title{
ROLE OF PLANNING AND MANAGEMENT IN PROMOTING URBAN DEVELOPMENT: CASE STUDY OF JEDDAH, SAUDI ARABIA
}

\section{Hisham M A. Gadou, and}

Associate Professor, Ain Shams Uni., Faculty of Engineering, Dept. of Urban

Design \& Planning, Cairo, Egypt - E-mail: hishgadou08@gmail.com

\section{Akef M. A. Quazi}

Professor, College of Architecture and Planning, King Faisal University, Saudi Arabia - E-mail: akefq2001@yahoo.com

(Received November 27, 2008 Accepted January 17, 2009)

In Saudi Arabia, an array of diverse strategies has been applied in response to the adverse effects of urban sprawl. A review of the historical proliferation of these strategies indicates that although in the short term the strategies have achieved high-quality infrastructure in some parts of the major cities, longer term prospects are less promising since numerous urban problems persist in these cities. Among these problems are uncontrolled developments in the fringes, inadequate urban services, spiraling land prices and construction costs, proliferation of slums and degrading quality of the urban environment.

This article reviews the urbanization process in Jeddah and outlines in brief the historical evolution of urban planning and development of the city. The paper, using qualitative methodology, investigates and highlights the need to integrate physical planning with urban development management. Attention is paid to the role of the municipal authority and the extent of its legal and fiscal discretion, inter-agency coordination and community participation, all of which, the paper concludes are central to municipal management and optimization of the effect of public policies and urban planning.

This paper is organized into four major sections. The first section provides a brief review of public policy instruments for urban growth management. The second section illustrates some issues and challenges that have been encountered during the rapidly growing urban population in Jeddah. Here, some light has been shed on the public policies adopted for growth management as well as on the characteristics and the nature of urban planning and management systems. The third section focuses on the recent administrative reform and the current strategies adopted by the government for improvement in urban development management. In the final section, the paper focuses on the implementation of current views on how local authority and other stakeholders could be organized in order to take effective action and bring about meaningful urban development in Jeddah

KEYWORDS: Urbanization; Urban sprawl; Urban Growth Boundary, Growth Management; Public policy; Participation; Structure 


\section{Planning, Corporate Planning}

\section{INTRODUCTION}

Since the formal establishment of the Kingdom of Saudi Arabia (1932) political and administrative leadership has considered urban development essential for the economic and social well-being of the citizens. Initially urban growth was promoted by expanding the municipal area boundaries as well as other components of urban structure and thus enabling economic growth and population increase. Till date, urban growth and development continues to be the main strategic tool for sustained economic growth of the country. By and large, urban growth has been perceived beneficial because of the outstanding achievements in infrastructure and services and a parallel rise in the standards of living in a short period of time [18].

However, over the last two decades urban analysts and social commentators have started to point out that negative externalities in environmental, social and economic terms outweigh the benefits. They argue that the development policies so far have been self-defeating because they failed to allocate resources in a balanced manner [21];[26] which has resulted in a distorted nature of urbanization, [5] manifest in 'leapfrogging development', proliferation of scattered settlements, unregulated urban fringe, shortage of affordable housing, insufficiently funded public services, increasing social differences, long commuting times, traffic congestion, and notable ecological problems.

The phenomena of excessive urban growth, which has recently been placed on the Saudi national planning agenda, can be attributed to the inherited legacy of conventional urban planning practices and actions for regulating urban development and service delivery. It has been pointed out [18] that due to the lack of appropriate policy guidance and the absence of coordination among government agencies, the public sector authorities could not perform the duties assigned to them. Moreover, the municipalities seemed poorly equipped to deal with the massive forces of urbanization. Expansion of the administrative jurisdiction within cities required a greater degree of control over the area than the local authority was able to exercise. It can be said that the laissez-faire attitude towards the urbanization process and uncontrolled urban sprawl has developed because of the weakness in urban management system and limited manpower and legal power. Clearly, it is not urban growth itself which is the problem, rather the rate and pattern of that growth, which outpaces the institutional, administrative and financial capabilities to cope with it. The primary question decision makers and scholars should now pose is how to assist the local authorities in formulating long-term objectives and enable them to effectively manage the potential impact of oncoming urban growth.

\section{OBSERVATIONS ON URBANIZATION AND PUBLIC POLICY INSTRUMENTS}

\subsection{The Challenge of the Urbanization Process}

The impacts of rapid urbanization worldwide are being increasingly recognized at national and international levels. The demands of growing populations in cities and the problems caused by their rapid growth raise a number of issues that have been addressed 
internationally. The 2006 State of the World's Cities Report [45], for example, highlights that the contemporary pattern of urban development is a reflection of unbalanced/unguided urban growth. Accordingly, the report stressed the importance of balance in addressing these problems as well as to ensure formulation of effective longterm urban development policies [45]. The concern for unguided urban growth has also forced many cities in Europe and the USA to employ innovative planning approaches such as the idea of 'smart growth policies' and 'new urbanism planning criteria' to encourage compact development [25].

\subsection{Public Policy Instruments for Urban Growth Management}

The growing literature on urban growth management tends to describe policy instruments rather than evaluating their effectiveness on the pattern of urban expansion [9]. It can be attributed to the lack of reliable data, empirical evidence, and contradictory evidence as to the effectiveness of the tools, and/or the absence of appropriate policy. Furthermore, growth management policies are only one of many dynamic factors that influence urban development patterns. The other factors are: effects of the natural environment, the effects of demographics, the rate of economic growth, development priorities, the effects of the transport system, private and public resources, the changes in consumer preference and desires, and governance mode [9] ; [13]. While a policy for managing urban growth needs a long period of time before it can work smoothly and have an impact, stakeholders often expect short-term results [20]. But short-term evaluations for public policy and city management may not be enough to detect its effectiveness or identify its consequences. Therefore, determining whether or not a program has been effective requires time and clarity regarding its intention and objectives [13].

The growth management tools and techniques such as urban growth boundary (UGB) may appear conceptually simple, but obviously it is difficult to implement. Therefore, in preparing a public policy we need to not only ask what type of policy instrument might be effective, but also how that policy would be implemented or enforced [40] ; [46]. Policies, plans, programs, and techniques, however good in themselves, will not succeed if they cannot be implemented properly. Research indicates that the failure of many growth management programs often result from the lack of strong and autonomous municipal authority [14]. Nelson and Duncan (1995) point out that proper implementation of the policies of development management is the key factor for their success [14] argues that 'the level of complexity of policy subsystem and the technical capacity of government affect the chances of success of a specific policy tool.' Others assert that the task of vertical and horizontal coordination of the actions of different governmental and non-governmental agencies and stakeholders is at the heart of growth management [30]. Above all, clear understanding of the complexity of urban growth policy and the strengths and weaknesses of specific management techniques is necessary to improve the effectiveness of urban growth management programs [14].

With a view to developing an innovative approach to contain rapid urbanization, the United Nations Development Program (UNDP), the United Nations Human Settlements Program (UN-Habitat), and the World Bank introduced Urban Management Program [48]. Despite the significant differences in institutional and 
operational aims of these multilateral agencies, they stress the importance of strengthening local government and coordinated inter-agency programmatic approaches to urban policy and management [32]. It appears that most of the approaches and techniques have stimulated a shift of emphasis from the conventional spatial planning techniques towards the concepts of 'public policy management' and 'strategic thinking' [45].

In 2001 UN-Habitat made a contribution ('Toolkit to Support Participatory Urban Decision-Making') to popularize the concept of 'Inclusive City'. This publication was aimed at enhancing knowledge and capacities of local authorities and their partners by improving the quality of urban governance and helping to institutionalize participatory approaches. It identifies a four-phased approach to participatory urban decision-making: (i) stakeholder mobilization; (ii) issue prioritization and stakeholder commitment; (iii) strategy formulation and implementation; and (iv) follow-up and consolidation [45]. Similarly, [27] developed a manual for the enhancement of the effectiveness of city and municipal planning management through the use of a 'partnership approach'. They assert that successful urban development can be attained 'when actors come together to achieve a common goal based on agreed priorities, pooling resources and maximizing comparative advantage' [27]. Clearly, realization of civil life such as 'participation', 'partnership', and 'inclusive city' entails genuine political will and an institutional environment that would allow their realization.

Experience so far shows that public participation is an essential means to achieve good governance and the 'Inclusive City'[45]. Public participation in this context could be effective if it is based on mutual trust and cooperation among all stakeholders involved in the development process [11]. But it must be warned that while there are strong supportive arguments for the importance of participation in the decision-making process, there are also associated risks in incorporating participatory approaches in some circumstances. While some commentators (e.g. [1] ; [27]) argue that participation assists in building local capacities in regulating and negotiating development activities through learning by doing, others (e.g. [42]) point out that such participation can disturb the existing sociopolitical system and create a destabilizing force, foster intolerance, increase costs which in turn may cause delays or discontinuity in development efforts. Numerous constraints can hamper meaningful participation in the decision-making process. These include: time constraints, limited fiscal and human resources, lack of willingness of stakeholders or individuals to participate, lack of trust, and the nature of the problem [42].Therefore, the degree of stakeholders' involvement in preparing and implementing development initiatives needs to be carefully studied and adapted [27].

Another popular strand of thinking in respect of public participation and good governance points out that communication between the planning and development agencies and the intended beneficiaries/stakeholders are essential prerequisites for successful urban management [29].

\section{REGULATING URBAN GROWTH PROCESSES IN SAUDI ARABIA}

The urban growth process in Saudi Arabia is one of the world's fastest. The prime urban centers like Riyadh, Jeddah, Makkah, Madinah, and Dammam, have experienced explosive 
growth since 1973. According to the National Population Census of 2004, the population has grown at a rate of $2.4 \%$ per annum from 16.94 million in 1992 to 22.7 million in 2004, an increase of 5.72 million (33.8\%) - [33]. The gross density of Saudi cities is significantly low, ranging from 12 to 29 persons per hectare [34]. This indicates that the share of the population living outside the central city is increasing. Such urban sprawl has been forcing municipalities to expand their boundaries in order to serve the urban fringe. This policy option and management strategy to accommodate urban expansion has lead to premature expansion of public infrastructure networks [9]. This in turn has led to imbalanced urban growth.

Urban sprawl in Saudi Arabia has gone unabated so far by the public laissezfaire in urban development. Impact of the land grant policy and interest-free loans by government agencies during the last four decades can be cited as factors responsible for the urban sprawl phenomena in the KSA. Through these policies, hundreds of thousands of residential plots were distributed free of cost to the general public. Above all, the enthusiasm of real estate developers have been a significant force in the premature and unprecedented expansion of suburban areas in major cities such as Riyadh and Jeddah and Dammam.. This in turn necessitated the rapid expansion of the road networks and utilities with high financial outlays [5].

According to some estimates, the population of Saudi Arabia may reach from 24 to 39 million by the year 2020. The urban share of the national population is expected to reach $86 \%$ by the same year [6]. Since such a rapid growth seems very likely, it would be a mistake to assume that urban growth will be contained in major urban centres or rural-urban migration will be limited. Since the cost of unchecked urban expansion is already so high, the question we need to address is how to make growth management policies and instruments more effective?

\subsection{Urban Growth in Jeddah}

Historically Jeddah has been performing important urban functions ${ }^{1}$ for the Arab peninsula. At the time of establishment of the Kingdom, Jeddah was the primate city of the newly formed state. At that time the ability of the government to intervene in regulating urban affairs all over the country was constrained by an absence of an institutional framework for both local and national governance and a lack of financial and human resources [6]. The fundamental challenge for the government during the 1940s was how to improve living conditions of the citizens. There was also a need to develop Jeddah as the western gate for the country, giving the city a role of national importance.

In 1937/38 an act was promulgated through a Royal Decree which empowered the

\footnotetext{
1 Jeddah is located on the Red Sea halfway along the western coast of Saudi Arabia. It is situated on a narrow coastal plain called Tihama. To the east are a number of small hills and farther inland is the high and steep Hijaz escarpment. The harbour in the city, from which pilgrim routes radiate inland to the holy places of Islam - Makkah and Medinahhas made it the primary commercial centre in the country. For a long time the city served as a diplomatic, commercial, distribution and service centre [15]; [22]. The social order in the city was homeostatic, adhering to the rules of the Islamic religion. By the time of the final establishment of Saudi Arabia (1932) and the unification of the Hijaz region, and up to the destruction of the city wall (1947), the functions, character and size of the city had remained virtually unchanged for centuries. [15] provides an elaborate analysis of the historical formation of Jeddah.
} 
establishment of local councils in the cities of Makah, Medina and Jeddah. ${ }^{1}$ This was the seminal step which stimulated the establishment of other municipalities in Saudi Arabia. After the Second World War, there was a period of political tension and struggles over the control of oil. During this period, the kingdom witnessed a sudden rise in its oil revenues and a dramatic increase in its urban population. In order to establish modernized institutional frameworks for the central government's planning apparatus, a new initiative was taken in 1953 aimed at establishing central authorities and to regulate both the interior and exterior affairs of the country. In the succeeding years, government's enlarged resources led to a dramatic increase in construction throughout the western (Hijaz) and the middle region (Najd) because a high proportion of the Kingdom's population concentrated there [18].

Fig. 1 Historical sequence of Jeddah development plans

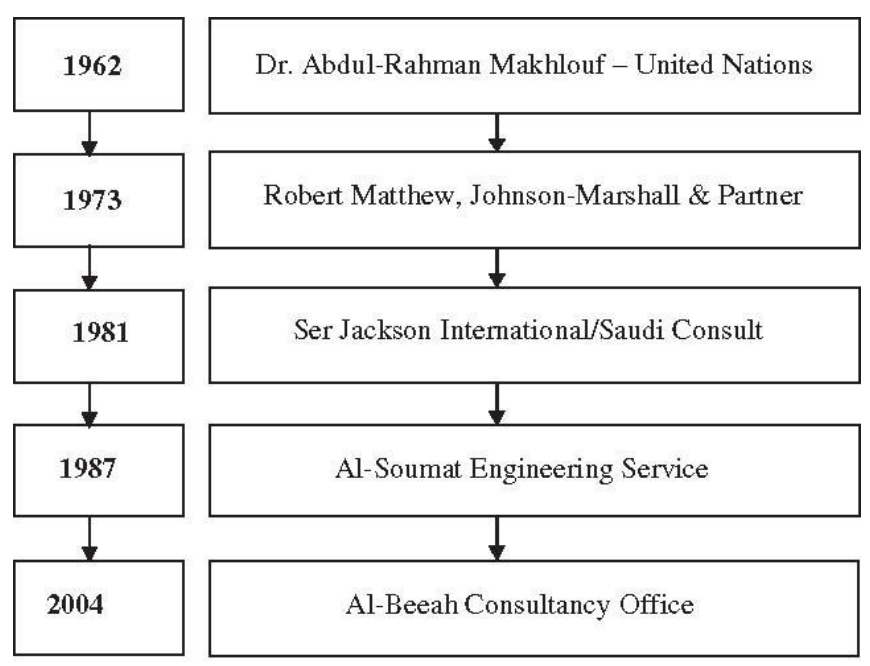

\footnotetext{
${ }^{1}$ This decree continued to be active until the Law of Villages and Municipalities was enacted in 1977. This act also stipulated the establishment of municipal administrations and their relationship with local municipal councils. Accordingly, lists of duties were assigned to the municipalities. Among these responsibilities were the supervision of the town development, monitoring housing conditions, regulating the extension and widening of streets, urban beautification and creation of public space, executing works needed for the enhancement of services, and improving the standards of living [12].
} 
Fig. 2. A view of Jeddah in 1940. Source: Pesce, A. (1977, p. 112): Jeddah Portrait of an Arabian City, London, Falcon Press

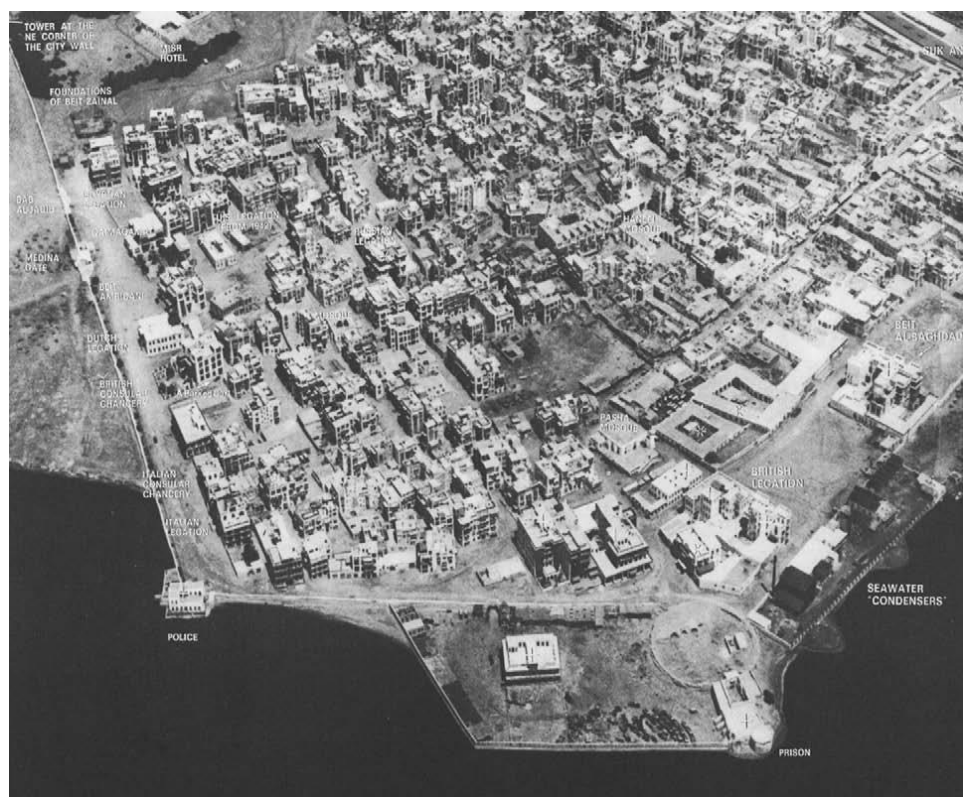

Fig.3. Formal residential area along Madinah road.

Source: Fadan (1977).

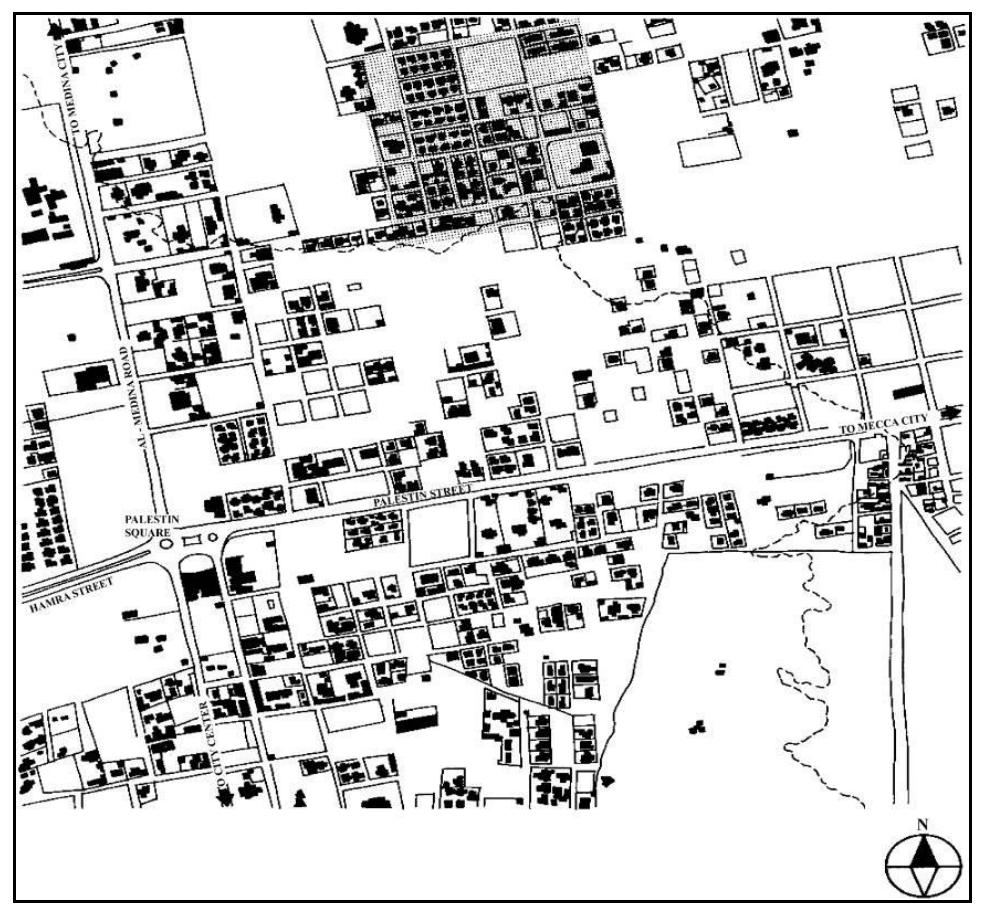

Ever since, the dynamics of the urban growth of Jeddah has entered a new phase. The city was allowed to expand through the process of extension of both formal and informal settlements outside the historic city walls. Some of the traditional neighborhoods were gradually transformed in line with the demands of urbanization. As a result, the estimated population of 35,000 in 1947 exploded to 150,000 by 1961 at an annual growth rate of $11 \%$. This high rate of growth fell slightly to $10.4 \%$ in the 
next 5 years, leading to 404,650 in 1971 , with a total increase in the built-up area of 1700 ha [7].

Following the institutional reform process of 1953, several governmental ministries and agencies were established. The Directorate of Municipality was created in the Ministry of Interior. In 1962, the Directorate was elevated to the Department of Municipal Affairs and then to Deputy in Ministry for Municipal Affairs in the Ministry of Interior, charged with the responsibility of urban planning and development of municipal services. However, development control was dependent on weak governmental by-laws passed during the earlier periods. Urban decisions were made in an ad hoc and short-term manner, limited to annual budgeting and mainly concentrated on addressing visible problems such as the construction of governmental buildings and internal city roads without thinking of long-term functioning of the city [26].

There were still other inadequacies in respect of managing the initial wave of urban growth. The absence of coordinated action on the part of public sector agencies was felt as the main area of deficiencies. Physical planning of the major urban centers including Jeddah remained isolated from the national context. The need for linking urban planning and national economic planning was felt and major reform and reorganization in the central government followed.

In 1960 a national planning authority named Supreme Planning Board was established. This institution was replaced by the Central Planning Organization in 1964 which was upgraded into the Ministry of Planning who prepared the first Five-year National Development Plan in 1970 marking the beginning of planned development in the kingdom. This national development plan established for the first time a link between economic planning at the national level and physical planning at the local. The plan identified key national development objectives and established targets for the different sectors of the national economy such as municipal services. The assistance of international experts also marked the beginning of local planning practices and led to the upgrading of urban administrations which were extremely poorly staffed. Generally speaking, at this stage the major challenge for the government was how to establish an institutional framework and a legal foundation to manage urban expansion and the growing demands for public services and community facilities.

\subsection{The Phase of Master Plan Approach (1970- 1980)}

With a view to ease up the housing and traffic congestion problems the government sought the help of the United Nation in preparing a master plan. The first master plan was produced in 1962 .

In 1971 the Ministry of Interior, Department of Municipal Affairs appointed Robert Matthew, Johnson-Marshall \& Partners to prepare a comprehensive Master Plan for Jeddah with a view to guiding different sectoral programs. The master plan was supposed to direct city development up till 1991. A principle objective of the master plan was to subdivide the city into various districts separated by arterial grid streets in order to provide formal access to land and easement for infrastructures. The implementation of the master plan objectives was facilitated by a set of planning regulations framed under zoning ordinances and land subdivision codes [12].

In 1975, a new ministry named Ministry of Municipal and Rural Affairs (MOMRA) was formed which facilitated a two tiers system of interaction between 
national economic planning and spatial planning at the national, regional and local levels as well as to provide and regulate infrastructure. However, the responsibilities still sometimes were shuttled between the tiers. Finally, MOMRA took control of drawing up the National Spatial Strategy (NSS).

By 1977, the national government turned its attention to reform programme for municipalities and enacted Law of Villages and Municipalities. This act annulled the previous Law of Municipal Governorate of 1937 and promulgated the present law governing the administrative and financial structure of municipalities. The objective of this reform was to promote financial and administrative decentralization and greater autonomy of action to fragile municipalities [6]. In accordance with the reform process of 1975, the organizational structure of Jeddah Municipality was revised in an effort to upgrade its performance. The new structure was re-arranged into departments of the municipality under the leadership of the Mayor to handle four main tasks: (i) technical affairs, (ii) municipal services management, (iii) land administration and (iv) internal administration. With the new reform process considerable discretion and more responsibilities were assigned to the municipality.

Fig. 4 Jeddah

Master Plan 1973

(Source Jeddah

Municipality)

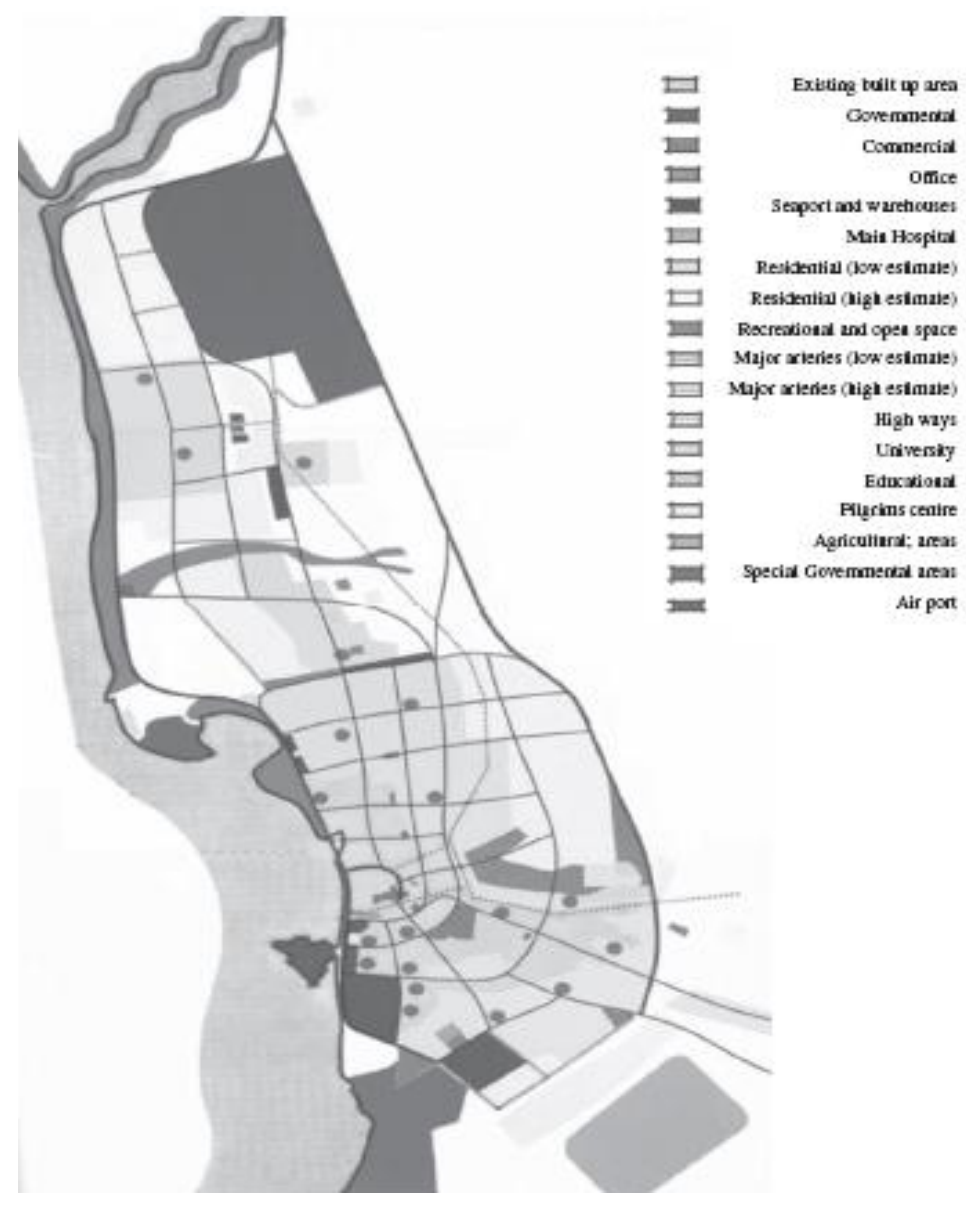

Accordingly, the Mayor reported directly to the Minister rather than through central ministry organization and the municipality became directly responsible for the 
preparation of physical plans, formulation of policies, supervision of project design, processing of contracts, and all aspects of project implementation. However, the capital budget remained subject to the Minister's approval [18].

It should be noted that although the new reform process of 1975 aimed at promoting administrative decentralization, the role of local municipalities in terms of physical planning remained limited. The actual task of physical master planning per se remained within MOMRA and development control function in the Jeddah Municipality remained mainly an administrative process such as granting planning permission and approving the subdivision of land. Moreover, the law empowered the Minister of MOMRA to establish the Municipal Council for a term of 4 years.

Municipal Councils were to be made up of an equal number of elected and appointed members while decisions of the council were passed by the majority of votes, the final approval being the responsibility of the Minister of MOMRA. In reality, however, a supreme steering committee was established in place of the Municipal Council. This committee was composed of representatives of various government agencies involved in the development of the city and was chaired by the Mayor [18] ; [26]. Despite the establishment of this committee, their role in directing urban land policy was still limited and they did not have the right to oppose development as long as it was in accord with the physical master planning done by the MOMRA.

This organizational anomaly can also be attributed to the fact that all public agencies in charge of construction of public utilities and community facilities at the local level were directed by their respective central ministries with very little local level co-ordination. These agencies not only have had their own independent programs and plans, but also employed different databases for their operational matters. [10] ; [12]; [15]; [26].

Apparently, the establishment of MOMRA and its corollary statute, the Law of Villages and Municipalities, amounts to a mere transfer of urban planning and management from one branch of the bureaucracy to another. The promotion of financial and administrative decentralization was true in the sense that a new specialized ministerial agency had become solely specialized in the development of national urban centres and other settlements. But greater autonomy for municipalities did not become a reality as they, together with local governmental agencies, continued to rely on the central Ministry of Finance for their annual budgets. Therefore, spatial planning continued to be isolated from national economic planning. The inception of MOMRA further increased the centralized role of central government in urban, regional and rural planning. Further, the well-intended restructuring in the process of urban planning encouraged the process of creating homologous urban forms for contemporary Saudi cities because Master Planning became a hermetically sealed central process involving bureaucrats, technocrats and expatriate planning consultants. Sadly, it substituted the creation of local governance with an extremely centralized bureaucracy. The scope of public participation was obliterated thus hindering the scope of local municipalities to have a positive impact on policy formulation and implementation or to address pro-actively the local problems of urban growth.

In 1977, the office of Sert Jackson International/Saudconsult was commissioned by MOMRA to review the previous master plan of Jeddah and to prepare action master plans at various scales that would illustrate the actual locations of the proposed land uses and public amenities network. The revised master plan was 
approved by the Council of Ministers in 1981 and adopted as official policy for regulating the city's development. The revised master plan promoted the application of the arterial gridiron pattern for street networks and land subdivisions throughout the city. It allowed for a range of uses and zoning regulations and also suggested the reduction of housing densities in the informal settlements through widening the existing street networks and regulating development patterns in the emerging formal residential areas [35].

During this stage (1970-1980), the city had undergone widespread urban sprawl. As consequences of rapid urban growth, Jeddah witnessed a substantial flow of new immigrants to the suburbs where the cost of living was more affordable for newcomers. People from around the country as well as other countries came together in a relatively short period of time and formed a sprawling metropolis. Consequently, the city grew at annual rate of about $7.6 \%$ between 1971 and 1978. The population of the city of 404,650 in 1971 increased to 1,312,000 in 1978. By 1987 the spatial coverage of the city expanded dramatically to an area of over $367 \mathrm{~km} 2$ [36].

Over the decade of 1970-80 various policies were employed which were mainly based on the incentive regulatory approach. Among the policies was the granting of thousands of serviced lots to citizens. This was further bolstered by the governmental policy of granting long-term interest-free loans through Real Estate Development Fund (REDF) in 1974 which started effectively granting interest-free loans to citizens in order for them to build homes. Consequently, thousands of houses and apartment buildings were constructed. It is particularly noteworthy that the housing shortage experienced during the early phase of the First 5-Year Plan (1970-1975) prompted the government to formulate an aggressive supply-oriented housing strategy during the Second and Third Development Plans, creating a housing surplus during the Fourth Development Plan period (1980-1985). Most of the housing projects remained empty because a large proportion of them were built speculatively when demand was high and landlords were reluctant to reduce rents and sale values [12]. In terms of the physical planning and policy instruments for urban growth management, the continued expansion of the city led to a massive building boom and the provision of various community facilities and public amenities. The publicly financed development projects in building major roads provided incentives for private sector developers in expanding housing projects and land subdivisions which in turn encouraged urban sprawl characterized by leap-frog pattern of development [10].

\subsection{The Phase of Regional Development Planning (1980 - 1990)}

Starting in the early 1980s numerous attempts were undertaken at the national level to coordinate the fragmented efforts of individual municipalities in respect of managing urban growth. The Fourth Five Year Plan (1985-1990) recognized the incompatibility between goals of the national economic policies and those of regional development. Regional planning was viewed as a public policy instrument that could resolve the potential conflicts between national and regional goals on the one hand and urban objectives on the other [10].

In 1985, in a reaction to the excessive spatial growth of cities, the Council of Ministers ordered a 2-year freeze on all urban expansion in the Kingdom and mandated MOMRA to prepare plans for urban growth boundaries. The principal objective of this 
policy was to designate future phases of development each 10 years to limit the supply of land for residential development and ban development in designated areas in the outskirts of cities. In accordance with the decree, Al-Soumat Engineering Services was requested by MOMRA to revise the previous Jeddah master plan and to prepare a comprehensive development plan that would guide the growth of city metropolitan area until 2025 [31]. The revised Jeddah master plan aimed at imposing development caps, but the timing of development was linked to the schedule timing of public improvement needed for development over the next 20 years, thus promoting in-fill development and redevelopment.

In 1989, the Council of Ministers approved the delineation of urban growth boundaries (UGB) for 100 Saudi urban centres including Jeddah for the next 50 years in designated phases, making it obligatory that municipal services will be provided only according to the respective development phases [10]. The UGB project was a technical exercise in which involvement of local municipalities was viewed indispensable and for this purpose a detailed and comprehensive manual was produced by MOMRA. ${ }^{1}$

Urban analysts (e.g. [10]) point out that the UGB actually has super-imposed land-use plans on the city structure producing a homologous city form for all the Saudi cities' as well as in pre-mature subdivisions. Others observe that the imposition was too stringent needlessly restricting the size of the city; and is responsible for excessive escalation in land value and house price. Still others (i.e. [5]) affirm that this policy could retain the potential for effectively limiting the city size and rationalizing urban development in the long run if it was adopted with greater care. Obviously, implementation of UGB requires an extension of existing zoning powers by the local authority. Instead, the municipal planners were compelled to move away from conventional land use control method and to adopt various ministerial directives and administrative memos for aggressively implementing urban growth boundaries. For example, to approve a new land subdivision in the suburban areas, the municipality officials followed the new 'ministerial directives' instead of referring to the zoning regulations contained in the the Master Plan of 1981. Often, municipality officials exercised more power forcing developers and individuals to adjust their decisions in accordance with new directives.

It must be reiterated that the main purpose of UGB was to slow down land speculation at the urban fringe. This goal could have been achieved by adopting a land policy that would permit the local authority to impose penalties on undeveloped lands. This would allow the forces of urban expansion to operate according to economic efficiency and social equity rather than by yielding profits only to the influential land owners. Given the context, it is necessary to understand of the fundamental forces that create excessive spatial growth. Among these forces are: (i) the tempo of national economic growth, (ii) the land market, (iii) popular attitudes towards real estate, (iv) the prevailing administrative and political system, and (v) the extent of governmental intervention. It is also important to understand the nature of effective remedies that regulate urban growth and allocate resources in a socially desirable manner [16].

\footnotetext{
${ }^{1}$ For a detailed discussion on the UGB please consult [5].
} 
In terms of urban management, the Jeddah municipality continued functioning as an agent for the central authority rather than as independent local authority [19]. Public authority is exercised directly through the UGB map and the related directives by the central authority, MOMRA. The lack of a strong team of planners, competent and dedicated support staff and the absence of realistic development control regulations together weakened the Municipality in the implementation of the Master Plan as well as in the enforcement of urban growth boundaries. The municipality also failed in effectively guiding the private sector investors as to the priority areas designated in the Master Plan.

However, the involvement of the Jeddah municipal officials in the preparation of the UGB enabled them to gain insight and receive training not only on the subject matter of UGB but also in techniques of population and estimates, urban threshold/holding capacity estimates, land requirement estimates etc. This experience is useful in promoting urban management competence and in the formulation of a cohesive urban management strategy. [5]. However, there was no direct public participation yet in identifying priority actions that would increase local acceptability of whatever policy is adopted to regulate urban growth. This can be attributed to the gaps in the institutional set-up, namely the absence of legal provisions that would allow public participation in decision-making and implementation process [26].

In summary, during this stage mixed public policy instruments and managerial efforts were employed to regulate the city's growth. Weakness in the local authority's organization and modus operendi prevented them from coping with huge waves of immigration and massive urban expansion. The expansion of the city's administrative jurisdiction required a greater degree of control over the area than the municipality was able to exercise. Regarding the spatial planning practices, it is to be noted that the rigidity of the master planning approach and the lack of inter-agency coordination led to the need for UGB as an urban management tool. This policy tool did not help create a balanced urban growth. Instead, it created more problems such as inflated land prices, shortage of affordable housing, greater conflict and confusion as to the future growth prospect for the city and the settlements in the surrounding region.

\subsection{The Phase of Structure Planning Approach (1990-Up-To-Date)}

With the start of the 1990s the phenomenon of regional disparities in spatial development began to be sufficiently highlighted. This stimulated the preparation of the National Spatial Strategy (NSS). The NSS suggested a system of 'growth poles' and 'growth centers' inter-connected by primary, secondary, and tertiary 'development corridors' based on the principles of 'efficiency-equity' which would harness the positive forces of the fast growing areas such as Jeddah city. It also provided a guideline for a balanced pattern of population distribution and settlement development. In the meantime the concept and practice of Structure Planning ${ }^{1}$ had gathered popular acceptance in the UK and other commonwealth countries. The NSS incorporated the

\footnotetext{
1 The concept of 'structure plan' which was initially developed by United Kingdom in 1968 is seen as a participatory urban management approach whereby urban development can be integrated with the physical planning approach and direct actions at local, regional, and national levels can be organized effectively because the concept can incorporate flexibility to adapt to the changing urban circumstances and socio-economic environment.
} 
concept of strategic plans (Structure Plan) to address the issues of lop-sided urban growth as well as to provide a broader framework for subsequent local plans which could also provide a basis for improved recourse allocation [10].

In 1989, the Council of Ministers directed MOMRA to undertake the preparation of Structure Plan for Saudi cities to guide their long-term growth. For the preparation of structure plans, individual municipalities were requested by MOMRA to consider redefining urban growth boundaries in order to cover much larger areas so that the problems that were being faced in the implementation of boundaries could be addressed effectively [5].

In 1995, a local consultant firm was appointed to prepare Structure Plan for Jeddah. The plan was mainly based on the idea of 'sustainable development' and intended to provide a broader spatial strategy for urban development within the metropolitan area up till 2055 (Fig. 5). To achieve the goals of the structure plan the consultant took account of some of the key objectives of NSS [37]. However, in preparing the structure plan, unforeseen problems were encountered because the structure plan approach requires wide range of interconnected development activities. This caused delay in preparing the plan. The delay in preparation has been due to a shortage of skilled planning staff, but also to an ambition to be comprehensive, to collect vast amount of data, and to involve too many committees and agencies in the planning process. Besides, since the approval of the NSS by the council of Ministers in 2001, no review or updating had been carried out to incorporate the fast structural changes that had changed the pattern of urbanization in Saudi Arabia [10].

In 2004, the same consultant was also requested to prepare a detailed local plan at scale 1:1000 and also to prepare detailed zoning regulations for selected areas. In early 2005 , applying the previous development directives, and planning bye-laws, the Jeddah Municipality approved a new local development plan to guide the city's growth up to 2055 in order to cope with the ongoing pressure of development. The plan attempted to utilize vacant lands in the city more fully, while increasing the height of existing buildings. In doing so, it clearly responded to the demands from the public. However, both the Structure Plan and the local development plans provided a feedback to the most recent zoning and subdivision regulations. The Structure Plan aimed at controlling horizontal growth by delineating the UGB on the one hand and by facilitating urban in-fill development on the other by deploying an incentives policy.

The underlying assumption of this local plan was that compact development would ensure efficient use of available land and maximize their profitability. It seems that policy makers at all levels were tempted to increase the incentive for upgrading and redevelopment by permitting more building densities and height within existing residential areas and on undeveloped land. It should be noted that if the decision to allow increasing densities was desirable and would maximize the return to real estate investment and ultimately would assist in shrinking the city size, then the loss from lower housing consumption would be offset by other gains such as improved access to open space and lower traffic congestion; and the consumers on balance would be better off' [16]. But if the criticism on urban sprawl is misguided by few benefits arising from increasing city density, such a decision may lead to a serious environmental deterioration, social problems and depressed standard of living in the city.

With regard to the structure planning process, although it was intended to cover all possible aspects of city planning, the relationship between different dimensions of 
planning such as social, economic, spatial and institutional remained ambiguous and fragmented. The lack of clarity about how to integrate the spatial planning system with development management objectives continues to hinder the local authorities to effectively implement the designated public policies and define the responsibilities of different public sector units. With regard to the implementation of the local plan of 2006 which calls for an in-fill development to make city more compact, it must be pointed out that the adoption of the Structure Plan necessitated formulation of new zoning regulations which further necessitated improvement in terms of skills and knowledge of municipal officials and professionals in order to successfully implement the new zoning regulations. Obviously the application of new regulations and/or policy instruments requires more institutional expedience as well as technical and administrative competence to resolve the expected conflicts, negotiations, complaints and confusions in the development process.

\section{RECENT INSTITUTIONAL REFORMS:}

In 1992/93, the national government introduced a new system of regional governance called the Consultative Council and Provincial System. The main task of the Consultative Council is to provide views and recommendations to central authority on ways to improve the development process at the provincial level, while the stated objective of the Provincial Council is to improve development management, preserve the rights of citizens and ensure their participation at regional and local levels, [6].

In 2003, the national government introduced another institutional reform in order to promote service delivery through a privatization process. This brought about a significant change in the political economy in the field of public service provision namely 'privatization of public amenities'. In accordance with the key objectives of the Seventh Five Year National Development Plan (2000-2005) and in an attempt to promote the overall urban management, the Council of Ministers issued a resolution that approved privatization of certain utilities and services including some municipal services. ${ }^{1}$

${ }^{1}$ Subsequently, MOMRA commissioned a study on privatizing municipal services which recommended a list of about 30 municipal services that could be privatized. Accordingly, Jeddah developed a list of municipal services that can be privatized such as city cleaning, pest control, outsourcing vehicle supply, recreational facilities and other services [2]. 
Fig. 5 Jeddah Structure Plan 2005. Source: Jeddah (2005).

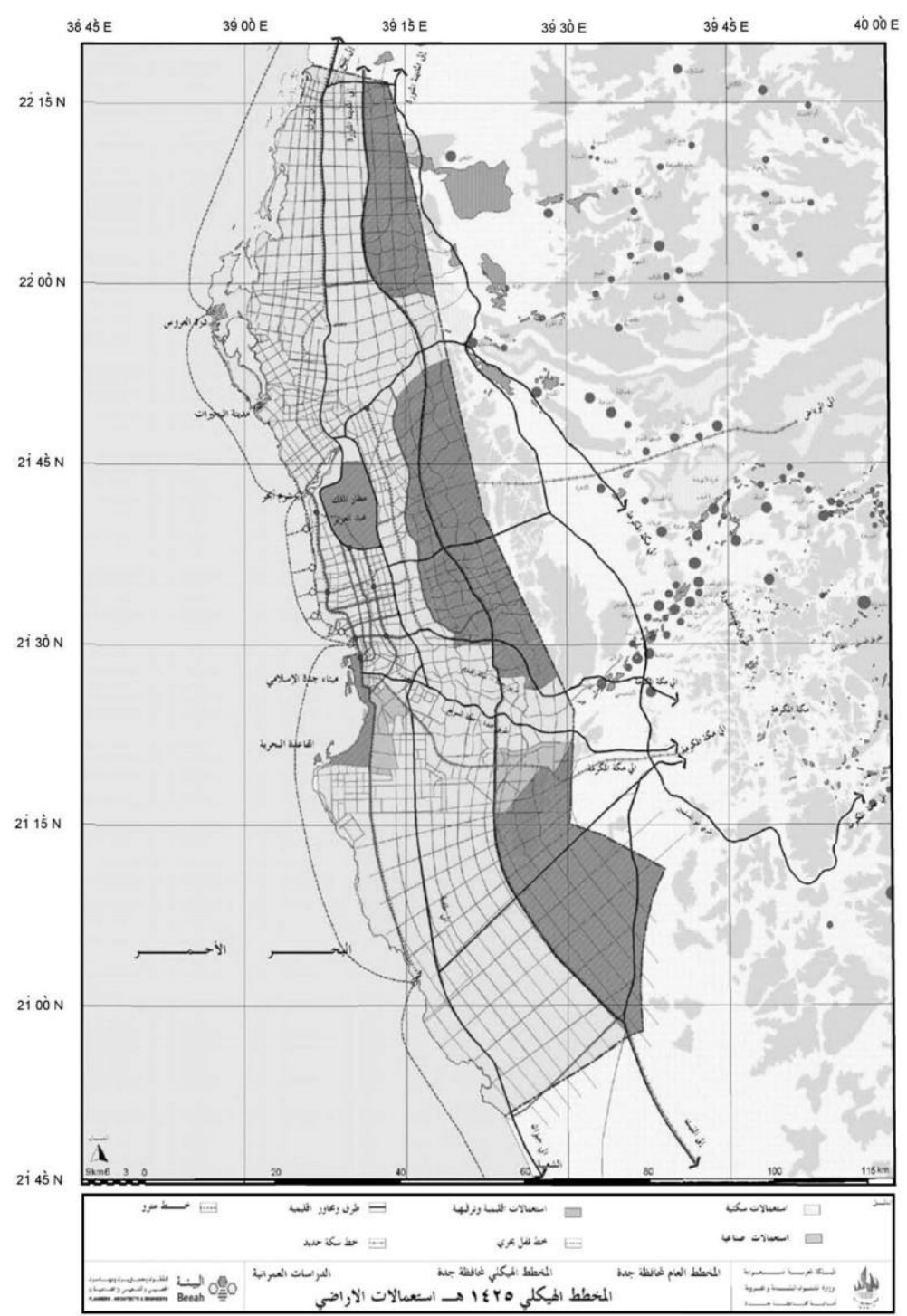

Although the central authorities support the idea of privatization, some institutional and organizational constraints still hinder the realization of this policy. One major problem is political. Even though the revenue earned from municipal investment through privatization would allow the reduction of government expenditure for service delivery, many social commentators in academic and private forums view this development decision as self-defeating. They argue that service delivery is a means to enhance civic responsibility; therefore, it is unrealistic to levy any direct or indirect fees on citizens for public services and infrastructure. Further, the lack of necessary knowledge base for assessing the advantages of public-private partnership has prevented both central and local authorities to develop a clear legal framework, performance dimensions or risk evaluations. Besides, the limited fiscal and legal power of local authorities compounded by a shortage of staff, limits the scope upon which municipal enterprise can develop. An account of such constraints is provided by 
Abdulaal's [2] article which documents the potential for public-private partnership in Jeddah.

In 2004, the Council of Ministers decided to allow half of the seats in 178 Municipal Councils in the Kingdom to be elected by popular vote. Although the Law of 1977 specified the duties, formation and delegated the authority to the Municipal Council to decide and monitor the performance and effectiveness in urban management of the individual municipalities, they were not instituted and empowered to function [1]. Four reasons can be identified as major constraints that minimized the role of the Municipal Councils in decision-making then. These include (1) centralization of political power, (2) rapidity of urban growth, (3) complexity of urban problems which forced the central authority to focus on immediate needs through centralized planning which would save time in service delivery, and (4) the weakness of administrative arrangements in local authorities.

In April 2005, half of Jeddah's 14 municipal council members were elected while the rest were appointed by MOMRA. ${ }^{1}$ It should be noted that Municipal Councils, as well as elections, are a new phenomenon in Saudi Arabia. At the time of their establishment, most local newspapers wrote of a giant step and initially greeted what they saw as a quantum leap towards better governance in society. These institutions, they pointed out would facilitate citizen participation [41]. Nevertheless, it must be stressed that the inauguration of the Municipal Council, the establishment of the Consultative Council, the Provincial Councils, and the Human Rights Association all clearly illustrate a transition in community engagement from ad hoc consultation to officially constituted institutions. Such moves will, it is to be hoped, create a widespread of urban planning and development management awareness in the country, particularly in decision-making at provincial (Mantaqah) and local levels. The staggering contests for seats on half of the Municipal Councils indicate that the idea of public participation in the planning and decision-making process is highly desirable and widely acknowledged by some scholars in promoting good governance in the cities of Saudi Arabia [1]. Such participation initiatives would eventually facilitate transparent decision-making and minimize the pressure exerted by central authorities.

The elected Municipal Councils do not only influence the decision-making process, but provide a new role for local people to develop negotiation skills within their communities. They also play an important role in monitoring and guiding local urban activities. Councilors seem to make sure local authorities perform their duties effectively and raise objections to any undesirable action. Broadly speaking, the participatory management approach has started to make local administrations publicly accountable. Moreover, the contribution of local councils also fosters more realistic urban planning practices and ensures respect for different viewpoints [11].

\footnotetext{
${ }^{1}$ Washington Post Foreign Service reported that the election of the Municipal Council in Jeddah ended in a sweeping victory for Islamic activists marketed as the 'Golden List' who used grass-roots organizing, digital technology and endorsements from religious leaders The Washington Post Foreign Service viewed the move as merely a token gesture. [17]. The Christian Science Monitor commented that the government's election-awareness campaign was insufficient because there were no grass-roots movements or civic societies available to energize the people to develop a certain stance for political life [8].
} 


\section{CONCLUSIONS AND RECOMMENDATIONS:}

A review of urban planning in Jeddah illustrates that achieving a balanced and manageable urban growth is a challenge for all public authorities in the Kingdom. Ever since the formation of the state in 1932, a diverse array of urban development plans have been followed aiming at regulating city growth and mitigating the adverse impacts of urbanization process. Few of these efforts succeeded. Deficiencies in these plans can be attributed to the shortage of qualified and competent manpower, absence of regional planning framework and lack of appropriate inter-agency institutional arrangement to link national economic policies with spatial planning.

The organizations that oversee urban planning are independent of those in charge of local implementation. Consequently, fragmented efforts and overlapping responsibilities become evident. Thus, an integrated planning system for spatial planning at different levels is urgently required in order to guide public sector activities to reach a common goal. Future trends towards more privatized service delivery demand a balanced strategy that emphasizes quantitative and qualitative aspects of public amenities in national urban land development policy, as well as regional and local planning. There is an urgent need to enact national legislation, and to provide for the updating of physical plans and development policies with special emphasis on implementation.

Jeddah's development is impacted by many stakeholders, including central and local authorities, developers, bankers, community development groups, and neighborhood residents. There is widespread agreement that the principal goal of urban planners and managers should be to enable individuals and communities to enhance their economic, social and spiritual well-being. Ensuring the 'maximum feasible participation' of stakeholders in the preparation of physical plans and in designing urban growth policies would help define priority tasks and actions. These are needed for attaining long-term objectives and achieving participatory planning. They are also essential for the creation of proactive strategies rather than prescriptive statements of urban development policies.

In view of the above conclusions it seems that in order to manage urban growth in Jeddah effectively it would be worthwhile to introduce the Corporate Approach ${ }^{1}$ in both planning and implementation where joint planning and coordinated implementation would be possible. The Jeddah local authority has an all round responsibility for the health, safety and general material and cultural well being of people in different localities. Such a comprehensive function cannot be performed by an organization with disparate departments. Therefore, corporate management function ought to be a prime objective of the Jeddah local authority.

The implications of a corporate approach in urban management would be that the local authority will have to work as a corporate body in terms of planning as well as implementation. The aim of the local authority should be to go for complementary planning of services rather than segmented administration of services. In this approach

\footnotetext{
${ }^{1}$ During the 1960s, with widening conceptualization of comprehensiveness, it was realized that major development issues for any local authority were all inter-related and that comprehensive socio-economic development required planned action in many areas simultaneously. Therefore, local authorities should work as one unified body in all kinds of development work for the sake of effectiveness. With a view to intervene and/or guide the complex interactive system of public services, Corporate Planning was advocated. (For a critical account of Corporate Planning please see Haughton G. \& William C. C. eds. 1996)
} 
the interdepartmental resources should be unified. Various public agencies at the local level posses and deploy varied kinds and qualities of resources - they own .land, buildings and equipments; they collect and store information; and they have their own staff resources; their skills and ideas and knowledge. All of these resources are normally utilized in a compartmentalized way as solely departmental properties rather than joint public resources. It is therefore imperative that the agencies pool their resources and thus optimize their use and effectiveness.

Corporate urban management function also calls for administrative efficiency and effectiveness. However, for this style of management to succeed there are organizational pre-requisites. It requires unified planning, programming and budgeting at local level. The greatest advantage that underlies corporate approach to planning is that it unifies the planning process. The aim is one planning activity drawing upon all the resources available at the local level to deal with the problems it faces. This would require a central policy committee whose chief responsibility would be to initiate the corporate planning process. From one unified planning process many plans for different departments could be generated for implementation purposes.

Further, corporate approach in planning also implies an up-to-date understanding of people's felt needs. It is pertinent to point out here that the Provincial System introduced in 1993 promises to usher in a new era of participatory development planning. It was widely acclaimed that the new system would be a good step towards providing a better role for regional government in the kingdom. It would facilitate a two-way system of development planning and thus of a participatory society. Similarly, implementation of the modernized Municipal Councils would have the same effect at the local level. Hopefully, by adopting the corporate system of planning and implementation the Jeddah Municipal Council could create a framework for effective local planning and successful development management for the city. It would facilitate people's participation in the decision-making process at both local and regional levels.

This in turn, it is hoped, will lead to popular democratic interpretation and implementation of physical plans and development policies and stimulate both the public and the private sector to accept full responsibility towards healthy growth of their city. Finally, it must be emphasized that when a local authority adopts Structure Planning involving wide range of inter-connected studies in order to first understand and then guide and manage its future growth in a comprehensive and effective manner, it would be most appropriate for it to adopt corporate approach for planning and implementation because inter-connected problem solving decisions cannot be solved with disparate actions.

Before closing, it is essential to note that while this paper advocates the merits of a participatory approach to the planning and decision-making process, for such participation to be meaningful and effective, cultural realities, political ideology, strength and quality of leadership in coordination, management capacity and the attitude of related stakeholders etc. could pose as the ultimate bottleneck which ought to be addressed simultaneously. Otherwise, the promises of participatory approach (both for public institutions and citizens alike) and corporate planning will remain a wishful thinking. 


\section{REFERENCES}

1. 1 - Abdulaal, W. (2006). Municipal Councils in Saudi Arabia: Context and organization. Journal of King Abdulaziz University: Environmental Design Science, 1, 1-25.

2. 2 - Abdulaal, W. (forthcoming). Potentials for private partnerships for Saudi municipalities. Journal of King Abdulaziz University: Environmental Design Science.

3. Al-Hathloul, S. (1981). Tradition, continuity and change in the physical environment. Unpublished Ph.D. thesis. M.I.T., MA.

4. Al-Hathloul, S., \& Abel-Rahman, M. (2003). Sustainability of development under pressure of fast urban transition: The case of Saudi Arabia. In the 6th Sharjah urban planning symposium, Sharjah, UAE (June).

5. Al-Hathloul, S., \& Mughal, M. (2004). Urban growth management-The Saudi experience. Habitat International, 28, 609-623.

6. Alkhedheiri, A. (2002). The role of secondary cities in national development process of Saudi Arabia, Riyadh.

7. Al-Otabi, A. (2006). Housing supply and demand in Northern Jeddah: Preferences and aspirations. Ph.D. thesis. University of Newcastle upon Tyne.

8. Ambah, F. S. (2005). Saudi democratic experiment ends on a flat note. The Christian Science Monitor. Boston, MA, USA (22 April).

9. Angel, S. (2007). Making room for a planet cities. Mimeo, Washington, DC.

10. Anis-ur-Rahmaan (2003). Optimizing the performance of environmental planning and design in Saudi society. Journal of King Abdulaziz University: Environmental Design Science, 1, 3-23.

11. Atmis, E., Ozden, S., et al. (2007). Public participation in forestry in Turkey. Ecological Economics, 62, 352-359.

12. Aziz-Alrahman, H. (1985). Review and analysis of land use regulations in Jeddah, Saudi Arabia. Unpublished M.S. thesis. Cardiff, University of Wales.

13. Bengston, D., Fletcher, J., et al. (2003). Public policies for managing urban growth and protecting open space: Policy instruments and lessons learned in the United States. Landscape and Urban Planning, 69(2004), 271-286.

14. Blair, R. (2001). Managing urban growth: Can the policy tools approach improve effectiveness? Public Works Management Policy, 6(2), 102-113.

15. Bokhari, A. (1978). Jeddah: A study in urban formation. Ph.D. thesis. University of Pennsylvania.

16. Brueckner, J. (2000). Urban sprawl: Diagnosis an remedies. International Regional Science Review, 23(2), 160-171.

17. Coll, B. S. (2005). Islamic activists sweep Saudi Council elections. Washington: Washington Post Foreign Service p. A17.

18. Daghistani, A. (1991). Urban growth management in Jeddah. Planning Outlook, 34(1).

19. Daghistani, A. (1993). A case study in planning implementation. Working paper no. 32. University of Newcastle upon Tyne.

20. Dekker, K., \& Kempen, R. (2004). Urban governance within the big cities policy. Cities, 21(2), 109-117. 
21. Eben-Saleh, M. (2001). The evolution of planning \& urban theory from the perspective of vernacular design: MOMRA initiatives in improving Saudi Arabian neighbourhoods. Land Use Policy, 18(2), 179-190.

22. Enani, M. A. (1998). Urban design and planning criteria for large-scale mixeduse developments (MXDs): Modern Saudi Arabian cities.

23. Ph.D. thesis. University of Pennsylvania. Fadan, Y. (1977). Urban dwelling environments: Jeddah, Saudi Arabia. Cambridge, MA: MIT Press.

24. Fishman, R. (2000). The American metropolis at century's end: Past and future influences. Housing Policy Debate, 11(1), 199-213.

25. Frenkel, A. (2004). The potential effect of national growth-management policy on urban sprawl and the depletion of open spaces and farmland. Land Use Policy, 21(4), 357-369.

26. Garba, S. (2004). Managing urban growth and development in the Riyadh metropolitan area, Saudi Arabia. Habitat International, 28, 593-608.

27. Hamdi, N., \& Majale, M. (2004). Partnerships in Urban Planning: A guide for municipalities. DataPrint (ITDG) Intermediate Technology Development Group.

28. Haughton G. \& William C. C. eds. (1996); Corporate City? Partnership, Participation and Partition in Urban Development in Leeds, Avebury Press, Aldershot.

29. Habermas, J. (1984); The Theory of Communicative Action: Reason \& the Rationalization of Society, Boston, Beacon.

30. Innes, J. (Ed.). (1993). Implementation state growth management in the United State: Strategies for coordination. Growth management: The planning challenge of 1990s. Newbury Park, CA: Sage.

31. Jenaideb, A. (1993). Dwellings and dwellers of a contemporary Madina. Ph.D. thesis. University of Strathyclyde.

32. Jenkins, P. (2000). Urban management, urban poverty and urban governance: Planning and land management in Maputo. Environment and Urbanization, 12(1), $137-152$ Available online at /http://eau.sagepub.com/cgi/content/abstract/12/1/137.

33. MOEP. (2004). Detailed Results Population \& Housing Census 1425 H (2004). Riyadh: Ministry of Economy and Planning, Central Department of Statistic \& Information.

34. MOMRA. (2001). The national spatial strategy. Riyadh, Saudi Arabia: Deputy Ministry for Town Planning.

35. Montgomery, S. (1986), Planning \& Urban Change in Saudi Arabia, Journal of Environmental Planning \& Management, 29(2), 74-79.

36. Municipality, J. (2004). Jeddah Structure Plan. Jeddah Municipality, Saudi Arabia.

37. Municipality, J. (2006). Jeddah Local Plan. Jeddah Municipality, Saudi Arabia.

38. NCPPR. (2002). Smart growth and its effects on housing markets: The new segregation. An econometric report by Quant-Econ for the Center for Environmental Justice of The National Center for Public Policy Research. Washington, DC. Nelson, A., \& Duncan, J. (1995). Growth Management Principles and Practice, American Planning Association: Planning Press. 
39. Ospina, S., Grau, N., et al. (2004). Performance evaluation, public management improvement and democratic accountability: Some lessons from Latin America. Public Management Review, 6(2), 229-251.

40. Porter, D. R. (1997). Managing growth in America's communities. Island Press: Washington, DC.

41. Qusti, R., \& Al-Salti, N. (2005). Landmark civic polls start today. Arab News (10 February). Jeddah.

42. Solitare, L. (2005). Prerequisite conditions for meaningful participation in Brownfield's redevelopment. Journal of Environmental Planning and Management, 48(6), 917-935.

43. UN-Habitat. (2001). Tools to support participatory urban decision making. Nairobi, Kenya: The United Nations Human Settlements Programme/United Nations (Habitat).

44. UN-Habitat. (2002). The Urban Management Programme, Newsletter. Nairobi, Kenya: The United Nations Human Settlements Programme/United Nations (Habitat).

45. UN-Habitat. (2006). 2006 Annual Report. Nairobi, Kenya: The United Nations Human Settlements Programme (Habitat).

46. Vendung, E. (Ed.). (1998). Policy instrument: Typologies and theories. Policy instrument \& their evaluation. New Brunswick, NJ: Transaction Publishers.

47. World Bank. (1991). Urban policy and economic development: An agenda for the 1990s. World Bank policy paper. Washington, DC.

\section{دور التخطيط والأداره العمرانية فى تعزيز التنمية الحضرية: \\ حاله دراسيه جده بالمملكه العربيه السعوديه}

طبقت المملكة العربية السعودية مجموعـة متتوعـة من الاستراتيجيات لمواجهة الآثار السلبية للامتداد

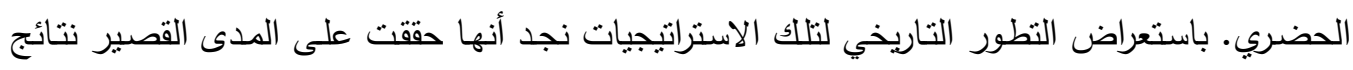
طيبه بالبنية التحتية في بعض أجزاء من المدن الكبرى. لكن على المدى الطويل فمن المتوقع أن تقل

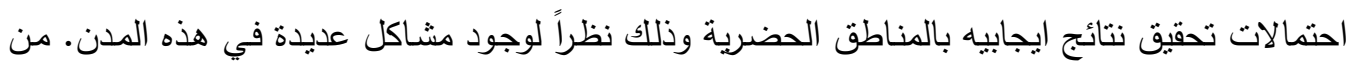

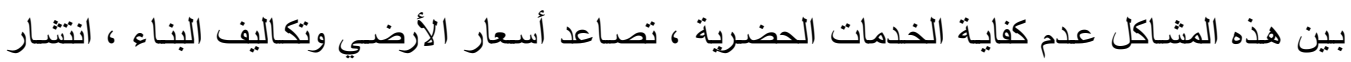
الأحياء الفقيرة وتدهور نوعية البيئة الحضرية.

ويستعرض هذا المقال عملية التحضر في مدينة جده من خـلال إلقاء الضوء على التطور التاريخي

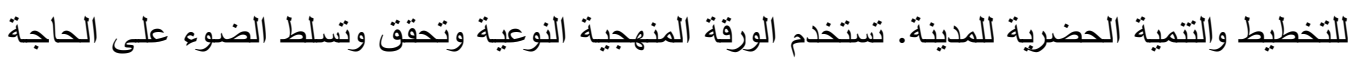
إلى تكامل التخطيط العمراني مع إدارة التتمية الحضرية. ومما هو جدير بالذكر أن هنالك اهتمام كبير 
لتعظيم دور سـلطه البلديـة مـن الناحيـة القانونيـة والاعتمــادات الماليـة والتتسيق بين الوكـالات الوزاريـة

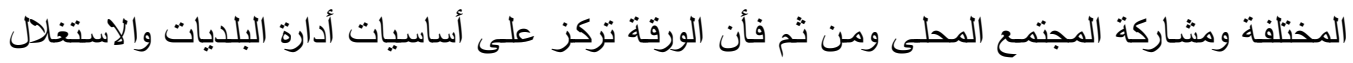
الأمتل للتأثير فى السياسات العامة والتخطيط الحضرئ الحئ تتكون هذه الورقة من أربعه أقسام رئيسيه نستعرض بالجزء الأول موجز لأدوات السياسة العامة لإدارة

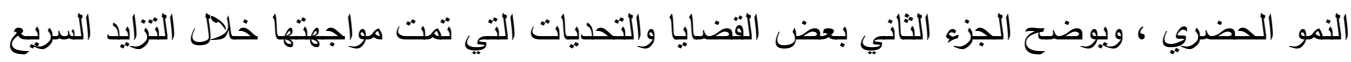

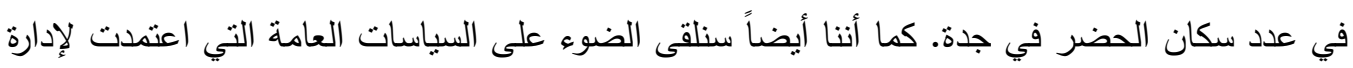

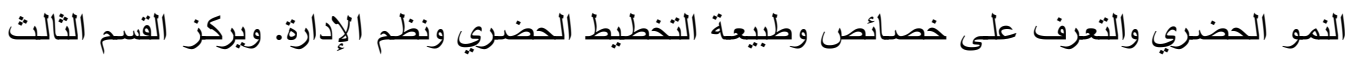
على آخر ما تم بالإصلاح الإداري والاستراتيجيات الحالية التي اتخذتها الحكومة لتحسين إدارة التتمية التحنية

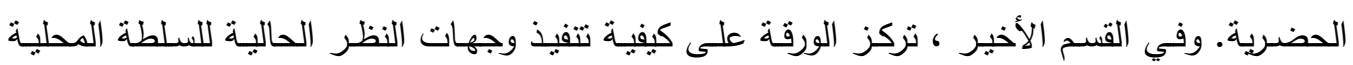

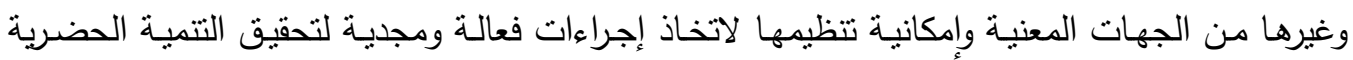
المناسبة في مدينة جدة. 